(Warszawa, PWT Bobolanum,

Rzym, Pontificio Istituto Orientale)

\title{
APOKRYFICZNY DIALOGUS IOHANNIS CUM IESU (CIAPNT 27) JAKO GNOSTYCKA REINTERPRETACJA DZIEJÓW PATRIARCHÓW I KOMENTARZ DO HBR 7, 3
}

Mianem Dialogu Jana Apostoła z Jezusem określamy fragmentaryczny tekst $\mathrm{z}$ kolekcji papirusów odnalezionych $\mathrm{w}$ Deir el-Bala'izah (dalej = P.Bal) ${ }^{1}$. W wyniku prac prowadzonych pod auspicjami Brytyjskiej Szkoły Archeologicznej i pod kierunkiem Williama M. Flinders Petriego w ruinach koptyjskiego monasteru dedykowanego prawdopodobnie św. Apollosowi w Deir el-Bala'izah w Górnym Egipcie, ok. $20 \mathrm{~km}$ na południe od Assyut (starożytne Lycopolis), na początku ubiegłego stulecia, zwłaszcza w latach 1906-1907, odnaleziono ok. trzech tysięcy fragmentów tekstów, głównie o charakterze liturgicznym i homiletycznym, pism hagiograficznych oraz biblijnych, w językach koptyjskim, greckim i arabskim² ${ }^{2}$. Większość odkrytych tam rękopisów pochodzi z VIII wieku, to znaczy z okresu szczególnego rozkwitu klasztoru, nie brakuje jednak znacznie starszych. Obecnie kolekcja z Bala'izah stanowi część Bodleian Library w Oxfordzie. Dokument interesujący nas bezpośrednio w zbiorach muzealnych otrzymał sygnaturę MS Copt. d $54 \mathrm{P}$. Badania nad tekstami z Bala'izah i ich publikację utrudnia przede wszystkim rozmiar kolekcji oraz fragmentaryczność dokumentów. Niektóre z nich przeanalizował i opublikował jeszcze Walter E. Crum, wykorzystując je w pracach nad swoim słownikiem języka koptyjskiego (pierwsze wydanie 1939). W roku 1954 Paul E. Kahle opublikował ponad 300 fragmentów z Bala'izah ${ }^{3}$. Jak dotąd jest to najobszerniejsza edycja tekstów pochodzących z tej kolekcji. We wstępie ogólnym Kahle przedstawił historię badań archeologicznych, omówił charakter znaleziska i zrelacjonował trudności związane z jego publi-

${ }^{1}$ Por. M. Geerard, Clavis Apocryphorum Novi Testatmenti 27: Dialogus Iohannis cum Iesu (fragmenta coptica), Turnhout 1992, 13.

${ }^{2} \mathrm{Na}$ temat dziejów prac archeologicznych prowadzonych w rejonie klasztoru św. Apollosa oraz ich rezultatów zob. P.E. Kahle, Bala'izah. Coptic Texts from Deir el-Bala'izah in Upper Egypt, t. 1, London 1954, 1-24; R.G. Coquin - M. Martin, Dayr al-Bala'yzah, w: A.S. Atiya (red.), The Coptic Encyclopedia, t. 3, New York 1991, 786-787.

${ }^{3}$ Por. Kahle, Bala'izah, t. 1-2, passim. 
kacją, wynikające przede wszystkim z bardzo złego stanu zachowania odnalezionych papirusów ${ }^{4}$.

1. Fragment P.Bal 52 i stan zachowania tekstu Dialogu Jana. Badania nad tekstem Dialogu Jana rozpoczęły się wraz z jego publikacją. Po raz pierwszy tekst koptyjski wraz z tłumaczeniem angielskim udostępnił W.E. Crum ${ }^{5}$. W edycji Kahle fragment ten ukazał się w układzie graficznym odzwierciedlającym stan zachowania dokumentu (jako P.Bal 52). Niemiecki badacz skorygował tekst wydany przez Cruma nanosząc kilka istotnych poprawek, głównie w wersetach 75-91, a całość opatrzył angielskim przekładem oraz krótkim komentarzem $^{6}$. Liczne uwagi do edycji całego korpusu w 1956 roku zgłosił jeszcze W.C. Till ${ }^{7}$.

Dokument P.Bal 52 składa się z trzech fragmentów (A - B - C). Rozmiary rękopisu 16 x $12,5 \mathrm{~cm}$. Tekst został zapisany uncjałą, w jednej kolumnie na obu stronach papirusu, jak w większości wczesnych rękopisów koptyjskich. Tylko jedna karta (fragm. B) zachowała się w stanie praktycznie nienaruszonym. Natomiast dwie pozostałe, w tym zwłaszcza strona pierwsza (fragm. A), są bardzo uszkodzone. Brakuje zarówno początku jak i zakończenia, co nie pozwala na określenie pierwotnego rozmiaru tekstu. Łącznie posiadamy 91 wersetów tekstu, w tym trzy grupy elementów zdobniczych, tzn. znaki podziału w połowie kolumny verso na stronie drugiej, oraz znaki podziału wyrazów na końcu linii. Fragment drugi (B) w wersetach 13. i 34. posiada oznaczenia stron:

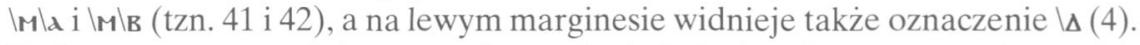
Każe to przypuszczać, że mamy do czynienia jedynie z fragmentem obszerniejszego tekstu. Analiza paleograficzna rękopisu wskazuje na IV lub V wiek ${ }^{8}$. Nie znamy jednak czasu powstania greckiego pierwowzoru tekstu, który zapewne był o wiele starszy. Dokument spisany został w dialekcie saidzkim języka koptyjskiego. Jest to jednak przekład z języka greckiego, na co wskazują liczne

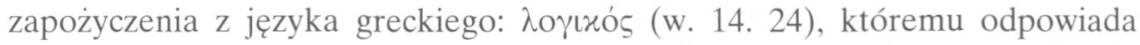

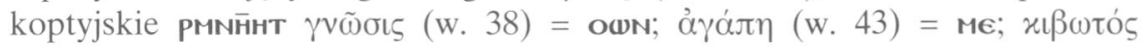

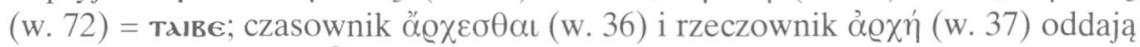
wartość słówka $\overline{\mathbf{c}} \boldsymbol{\omega} \mathbf{p r}^{9}$. Egzegetyczny charakter, prosty styl i krótka forma dokumentu mogą wskazywać, że tekst ten był przeznaczony dla gnostyckich neofitów. Liczne podobieństwa naszego fragmentu do gnostyckiego Apokryfu

${ }^{4}$ Por. Kahle, Bala'izah, t. 1, s. 1-14.

${ }_{5}^{5}$ Por. W.E. Crum, Coptic Anecdota. I: A Gnostic Fragment, JTS 44 (1943) 176-179.

${ }^{6}$ Por. Kahle, Bala'izah, t. 1, s. 473-477.

7 Por. W.C. Till, Zu den koptischen Texten aus Bala'izah, „Orientalia” 25 (1956) 384-403; uwagi do P.Bal 52 na s. 394 n.

${ }^{8}$ Por. Crum, Coptic Anecdota, s. 176-179.

9 Por. F.L. Horton, The Melchizedek Tradition. A critical examination of the sources to the Fifth Century A.D. and in the Epistle to the Hebrews, Cambridge 1976, 132. 
Jana mogłyby wskazywać na powstanie obydwu tekstów w podobnych środowiskach i czasie, być może już w połowie II wieku ${ }^{10}$. Ponieważ tekst P.Bal 52 jest stosunkowo krótki, przedstawiamy go w przekładzie polskim w pełnym brzmieniu i w układzie paleograficznym, zgodnie z wydaniem P.E. Kahle ${ }^{11}$ :

\section{Fragment A}

$1 \quad[\ldots]$

$\{$ recto; margines $\}$

$$
\begin{aligned}
& \text { cia }[\mathfrak{l}(\sigma \tilde{\omega} \mu \alpha) \\
& \text { nagie }[\ldots] \\
& {[\ldots] } \\
5 & \text { bezgrze }[\text { szny ...] } \\
& {[\ldots] }
\end{aligned}
$$

\section{$\{$ tekst urwany\}}

$$
\begin{aligned}
& \text { [4] [41] }
\end{aligned}
$$

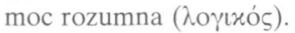

\{recto; margines strony\}

15 Zanim się objawiła

nie była jego imieniem,

lecz ( $\dot{\lambda} \lambda \hat{\alpha} \dot{\alpha})$ jego imieniem było

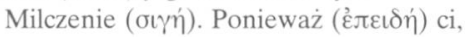

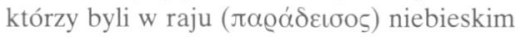

20 wszyscy zostali

opieczętowani w milczeniu.

Wszyscy, którzy je wezmą

przez to stają się

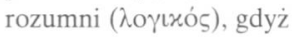

25 wszystko poznali. Pieczę-

tują oni pięć mocy

w milczeniu. Patrz, oto ja

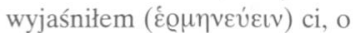

Janie, to co dotyczy

\section{\{verso; margines $\}$}

8 [...] twoja ręka \{albo: dla ciebie\}

$[\ldots](?)$

$10[\ldots]$ że (?)

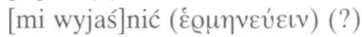

12 [to co odnosi się do Melchiz]edeka (?)

\{tekst urwany\}

\section{Fragment B}

\section{[42]}

\{verso; margines strony\}

35 ja, Jan, powiedziałem:

„Rozpocząłem (ǎ $\varrho \chi \varepsilon \sigma \theta \alpha)$

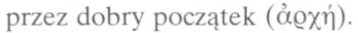

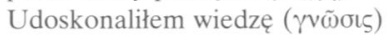

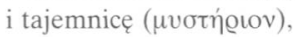

40 która jest zakryta, i w

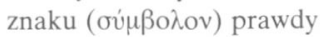

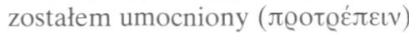

przez twoją miłość ( $\alpha \hat{\gamma} \alpha \dot{\pi}\rceil \eta)$.

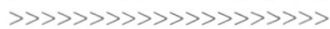

Chcę jednak ( $\delta \dot{)}$ jeszcze prosić cię,

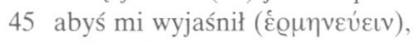

jeśli zechcesz, to

co odnosi się do Kaina i Abla:

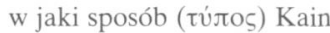

zabił Abla? Lecz ( $\delta \dot{)})$

${ }^{10}$ Por. M.R. Wilson, Gnosis and the New Testament, Philadelphia 1968, 103-104. Tekst ApokrJ zachował się aż w czterech odpisach i formach redakcyjnych, które odnajdujemy w następujących rękopisach: BG 2; NHC II.1; III.1; IV.1. Polski przekład ApokrJ według NHC II.1 wraz z komentarzem w: W. Myszor, Apokryf Jana (NHC II, 1), SSHT 35 (2002) 73-89. Wszystkie podane cytaty apokryfu będą pochodziły z tego tłumaczenia. Istotniejsze podobieństwa ApokrJ i fragmentu z Bala'izah obserwujemy zwłaszcza w odniesieniu do NHC II.1 31, 23-24. Jednocześnie już F. Horton wskazywał na istotne różnice zachodzące pomiędzy owymi dokumentami. Fragm. 52 z Bala'izah - na ile pozwala to stwierdzić stan jego zachowania - zdaje się być przede wszystkim alegoryczną interpretacją wybranych postaci patriarchów, czego w ogóle nie obserwujemy w ApokrJ. Po drugie, dokumenty znacznie różnią się rozmiarami.

11 Tłumaczenie tekstu koptyjskiego na podstawie: Kahle, Bala’izah, t. 1, s. 474-475. Ten sam tekst koptyjski został przedrukowany w: M. Waldstein - F. Wisse, The Apocryphon of John. Synopsis of Nag Hammadi Codices II, 1; III, 1; and IV, 1 with BG 8520, 2 (NHMS, 33), Leiden - New YorkKöln 1995, 195. Znak zapytania w przekładzie wskazuje miejsca w tekście, w których zachowały się pojedyncze litery, jednak tekst nie jest możliwy do zinterpretowania lub wysoce wątpliwy. 


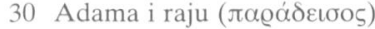

i pięciu drzew $w$

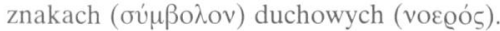

Gdy usłyszałem te rzeczy

$\{$ margines strony $\}$
50 nie tylko to, ale ( $\alpha \lambda \lambda \dot{\alpha})$ także był pytany przez kogoś, gdy rozmawiał z nim, mówiąc:

„Gdzie jest Abel, twój brat?". Kain

55 zaś ( $\delta \dot{)})$ wyparł się, mówiąc:

„Czy ( $\mu \eta \dot{)}$ ja jestem strażnikiem \{margines strony\}

\section{Fragment C}

$\{$ recto; margines strony $\}$

$[\ldots](?)$

$[\ldots](?)$

$[\ldots](?)$

60

$[\ldots](?)$

$[\ldots](?)$

$[\ldots](?)$

$[\ldots](?)$

$65[\ldots]$ i $[\ldots](?)$

$[\ldots](?)$

miejsce (

która jest doskonała. $\mathrm{O}[$ to]

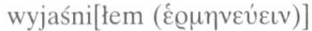

70 ci, Janie,

to, co dotyczy Noego i je[go]

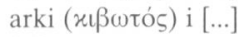

[...]

$\{$ tekst urwany $\}$ \{verso; margines strony $\}$

$75[\ldots](?)$

$[\ldots](?)$

[...] (?)

[chciałbym] jeszcze [prosić cię,]

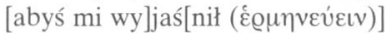

80 [to co do]tyczy Mel[chize-]

[deka. Czyż nie zos]tało powie[dziane]

[o nim,] że jest [bez ojca]

[i bez] matki, [że nie]

[wspomina się] jego pocho[dzenia ( $\gamma \varepsilon v \varepsilon \alpha ́)$ ]

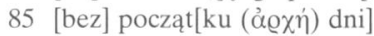

[i bez] końca ży[cia, będąc]

[po]dobny do sy[na]

[Bożego], będ[ąc]

[ka]płanem na wieki? Powiedzia[no]

90 [także] o nim, że [...]

$[\ldots]$

$\{$ tekst urwany

Dokument ma formę dialogu objawiającego, właściwą dla wielu tekstów gnostyckich $^{12}$. Gatunek ten łączy elementy charakterystyczne dla apokalipsy i apokryficznych dziejów apostolskich ${ }^{13}$. Powiernikiem objawienia jest tu za-

12 Formę dialogu objawiającego mają następujące teksty z Nag Hammadi: Apokryf Jana, apokryficzny List Jakuba, Hipostazy archontów, Księga Tomasza, Sophia Iesu Christi, Dialog Zbawcy, Pierwsza Apokalipsa Jakuba, Apokalipsa Piotra, Zostrianos, Melchizedek, List Piotra. Spoza korpusu z NH można wymienić przede wszystkim Pistis Sophia i obie Księgi Jeu z Codex Askewianus. Ponadto dialog objawiający Chrystusa z uczniami odnajdujemy m.in. w etiopskim Liście Apostołów i syryjskim Testamentum Domini Nostri Iesu Christi.

${ }^{13}$ W dialogach przekazuje się wiedzę dotyczącą podstawowych tematów gnostyckich, a więc opisu świata, kosmogonii, stworzenia człowieka, soteriologii i eschatologii. Zwykle pojawiają się także tematy szczególne oraz wyjaśnienia niektórych tekstów biblijnych, jak na przykład komentarz do Psalmów w traktacie Pistis Sophia. Na temat dialogu objawiającego jako gatunku literackiego zob. zwłaszcza K. Rudolph, Der gnostische Dialog als literarisches Genus, w: P. Nagel (wyd.), Probleme der koptischen Literatur, Halle-Wittenberg 1968, 85-107. W wielu systemach gnostyckich - zarówno chrześcijańskich, jak i czerpiących tylko z chrześcijańskiej tradycji - forma dialogu objawiającego pozwalała uwierzytelnić przekazywane treści dogmatyczne jako pochodzące wprost od Chrystusa i Jego apostołów. Wydaje się, że kontekstem takiej stylizacji mogła być 
pewne apostoł $\operatorname{Jan}^{14}$. O wiele trudniej odpowiedzieć na pytanie, kto jest rozmówcą apostoła, a więc pośrednikiem objawienia, gdyż jego imię nie zachowało się, a w dalszym ciągu tekstu brakuje jakichkolwiek wskazówek pozwalających na identyfikację. Rozwiązanie kwestii uzyskać można jedynie przez analogię. W wielu dialogach objawieniowych wiedzę tajemną przekazuje uczniom sam zmartwychwstały Chrystus ${ }^{15}$. Stąd też analizowany tu dokument zazwyczaj określa się mianem Dialogu Jana $z$ Jezusem $^{16}$. Niewykluczone jednak, że pośrednikiem objawienia jest tu po prostu jakiś anioł ${ }^{17}$.

2. Interpretacja dziejów patriarchów. Apostoł Jan zadaje pytania (w. 44nn

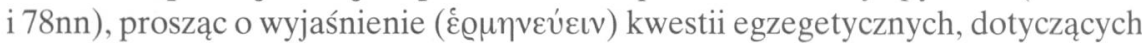
Księgi Rodzaju lub genezy i dziejów zbawienia. Na to jego rozmówca udziela

polemika z Wielkim Kościołem, którego luminarze - począwszy od św. Ireneusza - wskazywali na kompletność objawienia chrześcijańskiego, które nauczanie gnostyków jedynie zafałszowuje; por. B.A. Pearson, The Figure of Melchizedek in Gnostic Literature, w: Gnosticism, Judaism and Egyptian Christianity, Minneapolis 1990, 109.

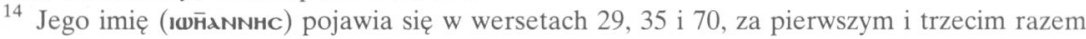
w formie wołacza. Apostoł Jan jest powiernikiem objawienia także w Apokryfie Jana (por. BG 2, 1; NHC II.1 1, 1-4) oraz w Pistis Sophia (np. 1PSoph 40; 2PSoph 63). W innych pismach gnostyckich do uprzywilejowanych uczniów, którym Zbawiciel powierza tajemną naukę, należą ponadto Tomasz Didymos, Piotr, Jakub i Maria Magdalena.

$15 \mathrm{Za}$ właściwy czas dla przekazywania takich pouczeń uważano przede wszystkim okres pomiędzy zmartwychwstaniem Zbawiciela a Jego wniebowstąpieniem. Długość tego okresu wobec „kanonicznych” czterdziestu dni (por. Dz 1,3-9) - w tekstach gnostyckich przybiera różną i zazwyczaj symboliczną wielkość: w Apokalipsie Jakuba mówi się o „kilku dniach” (por. NHC V.3 30,19 ), podczas gdy w apokryficznym Liście Jakuba okres ten trwa aż 515 dni (por. NHC I.2 2, 1921). W judeochrześcijańskim Wniebowstapieniu Izajasza $(9,16)$ mówi się o 545 dniach, co odpowiada liczbie 18 miesięcy nauczania Zbawcy, jak tego chcieli także walentynianie i ofici (zob. Irenaeus, $A d v$. haer. I 3, 2; I 30,14). W gnostyckim traktacie Pistis Sophia czas nauczania Jezusa po zmartwychwstaniu wydłuża się aż do jedenastu lat (por. 1PSoph 1). W Dialogu Zbawcy nie podaje się żadnych okoliczności rozmowy Zbawiciela z uczniami, por. A. Harnack, Chronologische Berechnung des Tags von Damaskus, Berlin 1912, 677-680; A. Orbe, Cristología gnóstica. Introducción a la soteriología de los siglos II y II, II, Madrid 1976, 521-531.

16 Tak w ClApNT 27. Tę samą opinię podtrzymują: H.M. Schenke (Die jüdische MelchisedekGestalt als Thema der Gnosis, w: W. Tröger (red.), Altes Testament-Frühjudentum-Gnosis. Neue Studien zu Gnosis und Bibel, Berlin 1980, 113), W. Myszor (Melchizedek w tekstach gnostyków, STV 22:1984, nr 1, 203) i B.A. Pearson (The Figure of Melchizedek in Gnostic Literature, s. 109). Natomiast J.E. Ménard (Le traité de Melchisédek de Nag Hammadi, RevSR 64: 1990, nr 3-4, 241) wskazuje na postać Zbawiciela, nie precyzując, czy chodzi o Jezusa Chrystusa, czy też ogólnie o postać gnostyckiego Zbawcy.

17 Por. Crum, Coptic Anecdota, s. 177; Horton, The Melchizedek Tradition, s. 135. Aniołowie jako wysłannicy Boga, przekazujący szczególną i tajemną wiedzę, pojawiają się najczęściej w pismach związanych ze środowiskami żydowskimi i judeochrześcijańskimi, jak to się dzieje np. w Księdze Henocha, Apokalipsie Barucha czy Wniebowstapieniu Izajasza i Pasterzu Hermasa. W niektórych tekstach z Nag Hammadi pośrednikiem objawienia jest anioł Gamaliel, por. np. Melch. (NHC IX.1 5, 18); ApAd (NHC V.5 75, 23); EwEg (por. NHC III.2, 52, 2; 64, 26; NHC IV.2 64, 15; 76, 17). 
odpowiedzi (w. 27nn i 69nn). Wyjaśnienia dokonuje on za pośrednictwem zna-

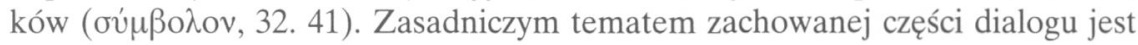
znaczenie postaci patriarchów. W tym kontekście spotykamy następujące imiona: Adam (дадам, 29n), Kain (кдлn, 47. 48. 54), Abel (дввєд, 47. 49. 53n), Noe ( $N \omega \bar{H} €$, w. 71). Być może objawienie dotyczyło także innych postaci, ich imiona jednak nie zachowały się ${ }^{18}$. Uszkodzone jest także imię Melchizedeka. Wskazuje się dwa miejsca, w których jego rekonstrukcja zdaje się uzasadniona, mianowicie

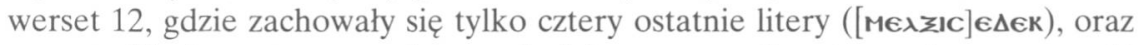
werset 81 i nastepny, gdzie $\mathrm{z}$ kolei mamy tylko trzy pierwsze znaki $\left(\operatorname{m\in \lambda }\left[z_{1} \mid c \in \Delta \in k\right]\right)$. Pomimo fragmentaryczności tekstu do tak zaproponowanej rekonstrukcji dotychczas nie zgłoszono poważniejszych zastrzeżeń. Analiza całości tekstu, zwłaszcza wersetów 78-91, zdaje się nie pozostawiać wątpliwości, że chodzi właśnie o tę postać ${ }^{19}$. Po raz pierwszy imię to pojawia się w zdaniu, które Kahle zinterpretował w brzmieniu: „wyjaśnić to, co odnosi się do Melchizedeka”

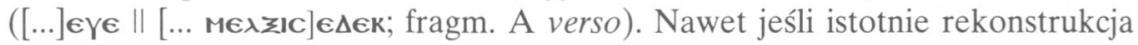
jest poprawna, nic pewnego nie potrafimy powiedzieć o jego kontekście. Być może stanowi go prośba apostoła Jana o wyjaśnienie znaczenia imienia Melchizedeka, jego roli w historii patriarchów lub w Księdze Rodzaju. Melchizedek byłby wówczas tylko jedną z omawianych postaci. Jednak umieszczenie takiej prośby na początku (?) zdaje się sugerować główny temat dialogu. Wówczas mielibyśmy sytuację, w której Melchizedek jest postacią centralną przekazywanego objawienia. Być może zapytanie odnosi się do typologii chrystologicznej Melchizedeka, co wskazywałoby na związek z Hbr, podobnie jak w NHC IX.1 $1^{20}$.

${ }^{18}$ Te same imiona patriarchów występują również w tekście ApokrJ (zwłaszcza 10, 18; 24, 25; 29, 2-15; por. Melch., NHC IX.1 12, 8). W systemach gnostyckich Adam jest zwykle ziemskim, to znaczy cielesnym obrazem człowieka niebiańskiego. Jego zrodzenie oraz dzieje upadku są szczególnym tematem antropologii i soteriologii gnostyckiej; por. K. Rudolf, Gnoza. Istota i historia późnoantycznej formacji religijnej, tłum. G. Sowiński, Kraków 1995, zwłaszcza s. 82-109. Na temat ezoterycznej interpretacji figury Adama w starożytnej literaturze żydowskiej zob. B. Barc, La taille cosmique d'Adam dans la littérature juive rabbinique dans trois premiers siècles après J.C., RevSR 49 (1975) nr 3, 173-185; N. Séd, La mystique cosmologique juive (Études Juives 16), Paris 1981. Imiona patriarchów powracają również w pismach apologetów jako przykład sprawiedliwych żyjących w przyjaźni z Bogiem jeszcze przed zawarciem przymierza z Abrahamem i przed nadaniem Prawa przez Mojżesza (por. Justinus, Dialogus cum Tryphone Iudaeo 19, 3-4; Tertullianus, Adversus Iudaeos 2; Ambrosius, De sacramentis 4, 6, 27). Lista sprawiedliwych kapłanów w modlitwie synagogalnej, zapisanej w Konstytucjach apostolskich, wymienia Abla, Seta, Enosza, Henocha, Noego i Melchizedeka (por. Const. apost. VIII 5, 3; por. także VII 39, 3; VIII 12). Podobnie w Kanonie rzymskim ofiara Abla wymieniana jest wraz z ofiarami Abrahama i Melchizedeka; por. P. Massi, Abel, Abramo e Melchisedech nel Canone, RivLit 53 (1966) 593-605.

19 Jak zauważył B.A. Pearson (The Figure of Melchizedek in Gnostic Literature, s. 109) ,of course, Melchizedek is not the only proper name that ends in - $₫ \Delta € \kappa$ (e.g. Adonizedek, Jehozadek), and it is not immediately evident what role Melchizedek might play in this particular context".

${ }^{20}$ Gnostycki traktat Melchizedek, zachowany fragmentarycznie tylko w kodeksie IX z Nag Hammadi, należy do tekstów setiańskich. Melchizedeka zdaje się być w nim uprzywilejowanym 
Wyrażenia „ciało” $(\sigma \tilde{\omega} \mu \alpha)^{21}$, „nagi”, „,bezgrzeszny”, które znajdujemy na początku fragmentu A recto (w. 1-6), zapewne odnoszą się do opisu stworzenia człowieka lub stanu pierwszych rodziców w raju (por. Rdz 1-3, zwłaszcza 2, 8 $25)^{22}$. Postaci Adama oraz Raju ( $\left.\propto \alpha \varrho \alpha ́ \delta \varepsilon เ \sigma o s ; 19.30\right)$ dotyczy także wyjaśnienie, które znajdujemy we fragmencie B recto (wersety 14-32). Postacie „prawdziwych", a więc duchowych i doskonałych prarodziców pojawiają się także

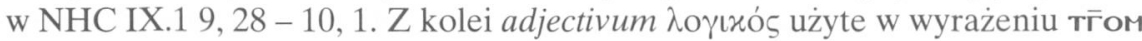
Nגorıkon („moc rozumna”, w. 14) oznacza naturę rozumną (por. Rz 12,1) i duchową (por. 1P 2, 2) ${ }^{23}$. Chodzi zatem o jakąś wyższą, a więc niebiańską rzeczywistość, będącą zapewne emanacją gnostyckiego bóstwa. Imieniem tej niebiańskiej mocy jest „milczenie” (сігн, w. 18); przynależy ono sposobowi istnienia poprzedzającemu objawienie się mocy (w. 15), a więc jakiejś formie

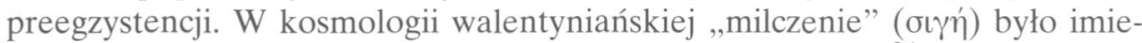
niem jednego $\mathrm{z}$ dwóch eonów, które poprzedzają stworzenie ${ }^{24}$. W innych tekstach z NH określenie to spotykamy w tym samym, lub podobnym, znaczeniu ${ }^{25}$. Jednak motyw milczenia czy też ciszy towarzyszącej przełomowym momentom w historii zbawienia spotykamy w różnych pismach wczesnochrześcijańskich.

odbiorcą objawienia, w którym powierzona mu zostaje szczególna misja w odniesieniu do uprzywilejowanej części ludzkości, mianowicie potomków Seta. Jest też pradawnym kapłanem Boga, odwzorowaniem prawdziwego, to znaczy niebiańskiego, Arcykapłana. W ramach powierzonej sobie misji Melchizedek składa Bogu ofiarę z samego siebie wraz z wybraną cząstką ludzkości, przeznaczoną do zbawienia, czego wyrazem jest szczególna liturgia połączona z obrzędem chrzcielnym. Powierza mu się także funkcję eschatologicznego wojownika i przywódcy w wojnie z archontycznymi mocami ciemności, kończącej się ostatecznym ich unicestwieniem. Także ten tekst wykazuje liczne paralele z Hbr. Wydanie tekstu W.P. Funk - J.P. Mahé - C. Gianotto, Melchisédek (NH IX,1). Oblation, baptême et vision dans la gnose séthienne (BCNH Textes, 28), Québec - Paris 2001, tłum. pol. W. Myszor: Melchizedek (NHC IX,1), STV 24 (1986) 209-226. Postać Melchizedeka w tekstach gnostyckich pojawia się ponadto w Drugiej Księdze Jeu oraz w traktacie Pistis Sophia; por. Myszor, Melchizedek w tekstach gnostyków, s. 203.

${ }^{21}$ Podobnie w ApokrJ znajdujemy opis postępowania archontów, aniołów i demonów, którzy trudzą się każdy przy jednej części psychicznego ciała ( $\sigma \tilde{\omega} \mu \alpha)$ Adama $(15,14-19,10)$, co z kolei bardzo przypomina żydowską kabalistykę. Później znajdujemy tam jeszcze opis ożywienia (animacji) Adama i udzielania mu pierwszych pouczeń.

${ }^{22}$ Por. Pearson, The Figure of Melchizedek in Gnostic Literature, s. 109. Natomiast J.P. Mahé wzmiankę o ciele i nagości odnosi nie tyle do sytuacji Adama, co raczej wiąże ją z nagością pieczołowicie strzeżoną przez człowieka żyjącego w samotności. Według tego badacza może się to odnosić do stanu, w jakim Abraham zastał Melchizedeka w opowieści, która została przekazana w korpusie pism św. Atanazego z Aleksandrii (por. PG 28, 528-529), jednak słusznie przy tym zauważa, że takiej tezy nie da się zweryfikować; zob. Funk - Mahé - Gianotto, Melchisédek, s. 20.

${ }^{23}$ Por. G.W.H. Lampe, A Patristic Greek Lexikon, Oxford 1961, 805; Crum, Coptic Anecdota, s. 177.

${ }^{24}$ Por. Irenaeus, Adversus haereses I 1, 1, SCh 264, 28-30.

25 Por. ApokrJ (NHC II.1 4, 14; III.1 10, 15); EwEg (NHC III.2 40-44; IV.2 58-60); Eugn. (jako imię Sophii, NHC III.3 8, 8-9); Sophia Jesu Christi (NHC III.4 112-118); Exp. Walent. (NHC XI.2 22, 24) a zwłaszcza w TrProt. (NHC XIII.1 35, 34; 37, 12. 29; 46, 12-21). Szczegółowy wykaz miejsc podaje F. Siegert , Nag-Hammadi-Register (WUNT, 26), Tübingen 1982, 300. 
Według Ignacego z Antiochii Chrystus jest Słowem Bożym „wychodzącym [od

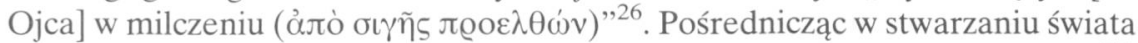
Logos sam działał w milczeniu i także przez milczenie daje się poznać światu ${ }^{27}$. O ciszy panującej w czasie, gdy Bóg stwarzał świat czytamy również w syryjskiej Księdze pszczoły ${ }^{28}$. Natomiast według autora koptyjskiej homilii o budowie świątyni Salomona, kiedy świat został stworzony panowała całkowita cisza, natomiast kiedy zostanie wydany na zagładę - dokona się to pośród huku i hałasu ${ }^{29}$. Dlatego też Przybytek Salomona został zbudowany w ciszy na podobieństwo stworzenia świata, a jego budowa jest także alegorią stworzenia

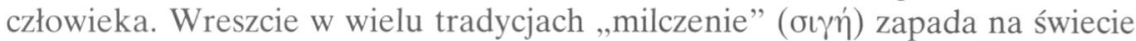
w czasie narodzin Zbawiciela i towarzyszy Jego złożeniu do grobu ${ }^{30}$.

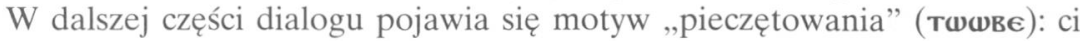
którzy przebywają w raju niebiańskim - a więc duchowy Adam i Ewa - „zostali opieczętowani w milczeniu” (w. 21) i przez to stali się istotami rozumnymi

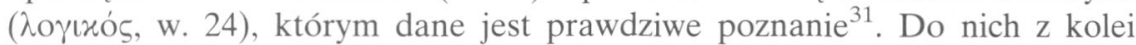
należy funkcja pieczętowania „pięciu mocy” (NT̄Trī̄om, w. 26), które zapewne należy utożsamiać z pięcioma drzewami ( $\overline{\mathbf{c}} \mathrm{HN})$, o których mowa w wersecie $31^{32}$. Pieczętowanie jest tu znakiem zachowania treści objawienia w tajemnicy wyłącznie dla wybranych, pneumatyków, którym dane jest prawdziwe, tzn.

${ }^{26}$ Por. Ignatius Antiochaenus, Epistula ad Magnesios 8, 2, SCh 10, 86, PSP 45, 75.

27 Por. tenże, Epistula ad Ephesios 15, 1, SCh 10, 70.

28 Tekst ten powiada, że kiedy Bóg zapragnął stworzyć cały świat, wszystkie byty rozumne i nierozumne, o których pomyślał i których zapragnął, była niedziela, pierwszy dzień, „wtedy stworzył siedem substancji w ciszy, bez dźwięku. A ponieważ wtedy nie było jeszcze nikogo, kto mógłby to usłyszeć, Bóg dokonał dzieła stworzenia w ciszy. I stały się zatem niebo, ziemia, woda, powietrze, ogień, aniołowie i ciemność - stały się z niczego" (Liber apis 2, ed. E.A.W. Budge, The Book of the Bee, Oxford 1886, 7).

29 Por. Ps-Basilius, Homilia de iudicio extremo et templo Salomonis coptice (CPG 2966), ed. E.A.W. Budge, Coptic homilies in the dialect of Upper Egypt, London 1910, 105-114, 248-257; P.J. Fedwick, Bibliotheca Basiliana Universalis, II 2, Turnhout 1996, 1223.

30 Według Ignacego z Antiochii ,nie pojął książę tego świata dziewictwa Maryi ani jej macierzyństwa, podobnie jak i śmierci Pana, owych trzech głośnych tajemnic, które dokonały się w ciszy Boga" (Epistula ad Ephesios 19, 1, PSP 45, 72). W apokryficznej Księdze o narodzeniu Zbawiciela 14 [72] czytamy, że w godzinie narodzenia wszystko pogrążyło się w wielkiej ciszy, znieruchomiały liście na drzewach i ucichło szemranie wód, zatrzymały się rzeki, nawet niebo wstrzymało swój bieg i nie odezwał się żaden ludzki głos: „czas ledwie mijał, a wszystko w wielkiej bojaźni milczało, trwając w zachwycie" (zob. ANT 1/1, Kraków 2003, 322).

31 Również w ostatniej części ApokrJ pojawia się zdanie „Ja go obudziłem i opieczętowałem

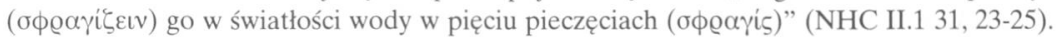

32 W ApokrJ pojawia się opis drzewa życia danego prarodzicom (ApokrJ NHC II.1 21, 24-25), które jest zarazem drzewem poznania dobra i zła (22,4-5). W gnostyckiej EwTm 19 pięć drzew ma najwyższą moc życiodajną. Motyw pięciu drzew spotkamy raz jeszcze w drugiej księdze Pistis Sophia: Opiekunowie Swiatłości wyłaniają się z pięciu drzew, by strzec i gromadzić światłość, jaka znajduje się ponad wszystkimi eonami i archontami, to znaczy w wyższych rejonach gnostyckiego świata (2PSoph 86, ed. C. Schmidt - V. MacDermot: Pistis Sophia, NHC 9, Leiden 1978, 194-195). 
duchowe, poznanie rzeczywistości ${ }^{33}$. Być może w naszym tekście pieczętowanie należy łączyć z rytem chrzcielnym, charakterystycznym przede wszystkim dla gnozy setiańskiej ${ }^{34}$. Motyw pieczęci należy jednak do szeroko pojętej literatury apokaliptycznej i pojawia się również w pismach należących do tradycji żydowskiej oraz judeochrześcijańskiej ${ }^{35}$.

Następuje odpowiedź Jana (w. 33-43), w której wychwala on pogłębienie udzielonej mu wiedzy ( $\gamma v \tilde{\omega} \sigma \iota \varsigma)$ oraz przekazanych tajemnic $\left(\mu v \sigma \tau \eta \dot{\varrho} \varrho\llcorner)^{36}\right.$.

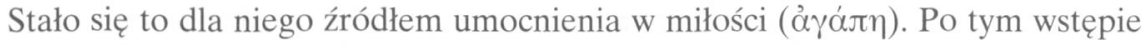
następuje prośba o wyjaśnienie historii Kaina i Abla (w. 39-56; por. Rdz 4, 1 16): w jaki sposób Kain zabił swojego brata i co oznaczają słowa „gdzie jest Abel, twój brat” oraz „czy jestem strażnikiem brata mojego” (por. Rdz 4, 9) ${ }^{37}$. Niestety, w tym miejscu tekst fragmentu B verso urywa się, w związku z czym nic nie potrafimy powiedzieć o treści tego wyjaśnienia ${ }^{38}$.

${ }^{33}$ Także w syryjskiej Jaskini skarbów Adam nakazuje nałożyć pieczęć na urnę ze swymi prochami (por. JasSkar 6, 9, CSCO 486/syr. 207, s. 51). Podobnie w etiopskich Zmaganiach Adama i Ewy pieczęcią opatrzono bramę arki, kiedy Noe opuścił ją po potopie (por. E. Trumpp, Der Kampf Adams, München 1881, 136). Z kolei w syryjskim Testamencie Adama opieczętowany został sam testament Prarodzica. W 2Hen 70, 17 pojawia się motyw tajemniczej pieczęci kapłaństwa, którą Melchizedek od urodzenia nosi na swej piersi.

${ }^{34}$ Por. J.M. Sevrin, Le dossier baptismal sèthien, Québec 1986; J.D. Turner, Typologies of the Sethian Gnostic Treatises from Nag Hammadi, w: L. Painchaud - A. Pasquier, Les Textes de Nag Hammadi et le probleme de leur classification (BCNH Etudes 3), Quebec - Louvain - Paris 1995, 167-217; tenże, Sethian gnosticism and the platonic tradition (BCNH Etudes 6), Quebec - Louvain Paris 2001, 238-242.

35 Znajdujemy go już w wizji Ezechiela, gdzie wybrani zostali naznaczeni literą tau (por. Ez 9 , 4). Ten sam motyw powraca w kanonicznej Apokalipsie Jana (Ap 6, 3-12; 7, 2; 9, 4; por. Pnp 8, 6; Hi

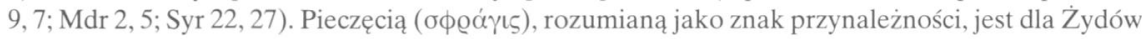
obrzezanie (por. Eusebius, Demonstratio evangelica I 6), a dla chrześcijan chrzest (por. Rz 4, 11; 2Kor 1, 22; 2Tm 2, 19; zob. Cyrillus Hierosolymitanus, Catechesis I 3). Obszerniej na ten temat zob. J. Daniélou, Teologia judeochrześcijańska. Historia doktryn chrześcijańskich przed Soborem Nicejskim, tłum. S. Basista, Kraków 2002, 381-384; S. Lilla, Sigillo, w: A. di Berardino (red.), Nuovo dizionario patristico e di antichità cristiane, t. 3, Genova - Milano 2008, kol. 4931-4934.

${ }^{36} \mathrm{~W}$ zakończeniu ApokrJ Zbawiciel mówi: „Dopełniłem dla ciebie wszystkie sprawy [...]. Powiedziałem ci wszystko, abyś to spisał i przekazał twoim współtowarzyszom ducha w sposób poufny. Jest to bowiem tajemnica ( $\mu v \sigma \tau \eta \dot{\varrho} \varrho$ v) niechwiejącego się pokolenia" (NHC II.1 31, 2629). Następnie narrator stwierdza: „I Zbawca dał mu je, aby je mógł spisać i przekazać potajem-

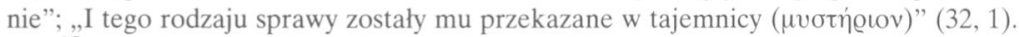

37 W ApokrJ imiona Kaina i Abla odpowiadają kolejno szóstej i siódmej z dwunastu mocy, które stwarza sobie pierwszy z archontów - Jaldabaoth (por. NHC II.1 10, 34-37). W tekście tym znajdujemy także gnostycki midrasz do opisu stworzenia Adama ,według obrazu pierwszego doskonałego człowieka" $(15,10 \mathrm{n})$, a w dalszej części pojawia się bardzo rozległa parafraza stworzenia Ewy i upadku prarodziców (aż do 25, 16), wraz z opisem zrodzenia Kaina i Abla (24, 25n), a potem Seta, będącego obrazem Syna Człowieczego $(25,1)$. Być może Set w tradycji właściwej Apokryfowi Jana spełnia tę samą funkcję, którą P.Bal 52 powierza Melchizedekowi.

${ }^{38}$ Tradycja zaliczająca Abla do grona sprawiedliwych bazuje na Rdz 4, 4 i powraca w Mt 23, 35; Hbr 11, 4; 1J 3, 12 oraz u Józefa Flawiusza (por. Antiquitates 1, 53). W Testamencie Abrahama 
Fragment C recto w swej początkowej części (wersety 58-66) jest praktycznie nieczytelny a zachowane znaki trudne do zinterpretowania ${ }^{39}$. Dalej zaś pojawia się tylko stwierdzenie, które można zinterpretować jako „miejsce Pleromy ( $\pi \lambda \eta \dot{\varrho} \omega \mu \alpha)$, która jest doskonała" (w. 67n). Zdanie następujące bezpośrednio po tym wskazuje zagadnienie, które było przedmiotem wyjaśnienia. Słowa te wypowiada pośrednik objawienia: ,wyjaśniłem ci Janie to, co dotyczy

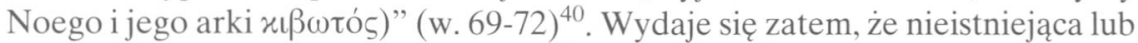
nieczytelna część fragmentu $\mathrm{C}$ recto zawierała pytanie i wyjaśnienie historii potopu (por. Rdz 6-8) ${ }^{41}$. Jest to jednak zbyt mały fragment ( 8 wersetów), by mógł pomieścić choćby pobieżne objaśnienie tego ważnego tekstu biblijnego. Należałoby zatem - wbrew opinii Kahle - dopuścić możliwość, że jedna strona rękopisu całkowicie zaginęła, albo też oczekiwać, że mamy tu do czynienia raczej z początkiem niż z zakończeniem spodziewanego wyjaśnienia ${ }^{42}$. Trudnością w takiej interpretacji jest werset 69 , gdzie użyta została forma czasu

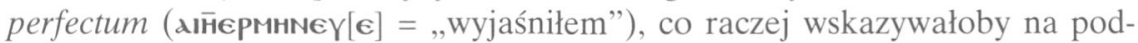
sumowanie tematu.

Abel, który nazwany jest pierwszym świadkiem, zasiada w raju na tronie, aby sądzić dusze $(13,2)$. W Homilii paschalnej Melitona z Sardes czytamy, że Chrystus „w Ablu był zabity” (Homilia paschalis 69, PSP 45, 235). O jakiejś księdze związanej w sposób szczególny z imieniem Abla wspomina Teodor bar Koni (IX wiek; por. Liber Scholiorum 11, CSCO 69, 342-343).

${ }^{39}$ Litery [...] $\overline{\mathbf{T}} \overline{\mathbf{T}} \mathrm{TH}[\ldots]$ w wersecie 60 mogą stanowić formę czasownika $\overline{\mathbf{T}} \overline{\mathrm{H}} \mathrm{TH}$ (,uważać, pilnować”; por. A. Dembska - W. Myszor, Podręczny stownik koptyjsko-polski, Warszawa 1996, 165. Natomiast $\mathbf{\epsilon} \overline{\mathbf{H}}$ Ү $\mathbf{N}$ w wersecie 66 zapewne należy nadać wartość „,w”, ,wewnątrz” lub „w środku” (tamże, s. 160), i związać ze wspomnianym w wersecie 67 „miejscem Pleromy”.

${ }^{40} \mathrm{~W}$ tekstach gnostyckich motyw arki powraca m.in. w EwFlp (NHC II.3 84, 34n); ApokrJ (NHC III.1 37, 23); ApAd (NHC V.5 70, 11. 20) i w piśmie pt. Myśl naszej wielkiej mocy (NHC VI.4 38, 30; 39, 3); por. J. Helderman, Die Bundeslade kibotôs. Ihre Geschichte als eine Metapher in der Umwelt der Manichaër, w: L. Cirillo - A. van Tongerloo (wyd.), Atti del terzo congresso internazionale di studi Manicheismo e Oriente cristiano antico, Louvain 1997, 125-148. Postać Noego w literaturze gnostyckiej, podobnie jak w całym piśmiennictwie żydowskim i chrześcijańskim, wiąże się zazwyczaj z historią potopu; por. Rdz 6-9; por. Tb 4, 3-21; Syr 44, 17n; 1Hen 106; Księga Jubileuszów 4, 28 - 10, 17; 1QapGen 2-6; Mt 24, 3-8; 1P 3, 20; 2P 2, 5-6; Hbr 11, 7; Origenes, In Genesim hom. 2, PSP 31/1, 40-55. Szerzej o symbolice Noego w literaturze wczesnochrześcijańskiej i jego typologii chrystologicznej zob. zwłaszcza E. Testa, La figura di Noe secondo i SS. Padri. Contributo alla storia dell'esegesi, SBF LA 20 (1970) 138-165.

${ }^{41}$ Ponownie analogię znajdziemy w Apokryfie Jana. Po komentarzu do opisu stworzenia następuje tam ciąg zapytań Jana i odpowiedzi Zbawiciela, dotyczących m.in. losu duszy i ciała oraz sposobu, w jaki Duch zstępuje na każdego $(25,16$ - 27, 31). Ostatnie zapytanie w tej części dotyczy przyczyn upadku ducha, będącego gnostycką parafrazą opisu biblijnego potopu (por. 29, 1nn). W tym kontekście pojawia się imię Noego (26, 2. 8). Ludzie nie posłuchali jednak napomnień patriarchy i nie schronili się w arce, ale ukryli się w „pewnym miejscu ... i w świetlistym obłoku”. Według tekstu z Nag Hammadi dopiero teraz nastąpił upadek ludzi i łączenie się archontów z córkami ludzkimi, czego konsekwencją była śmiertelność $(30,3)$.

${ }^{42}$ Zdaniem wydawcy tekstu, rękopis pod względem ilości stron jest kompletny, por. Kahle, Bala'izah, s. 473. 
3. Melchizedek i egzegeza Hbr 7, 3. Kolumna verso trzeciego fragmentu jest tak samo poważnie uszkodzona, jak kolumna recto. Trzy pierwsze wersety (75-77) pozostają nieczytelne ${ }^{43}$. Wersety 78-81 interpretuje się jako kolejną prośbę Jana skierowaną do pośrednika objawienia w kwestii egzegetycznej: „,chciałbym jeszcze prosić cię, abyś mi wyjaśnił to, co dotyczy Melchizedeka”. Następujące dalej wersety są albo dalszą częścią pytania postawionego przez Jana, albo też należą do udzielanej odpowiedzi. Druga ewentualność jest o tyle wątpliwa, że nie znajdujemy w tekście żadnej formuły wprowadzającej. Należy zatem pozostać przy propozycji Kahle, aby następujący tekst traktować jako wypowiedź Jana ${ }^{44}$. Wprowadza go pytanie postawione $\mathrm{w}$ formie negatywnej:

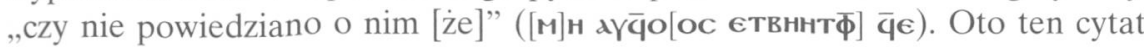
(w. 81-89):

oү[атеінт пе] [EOYdT]MdaY E[MாOY] $[\overline{\mathbf{C}} \lambda \overline{\mathrm{q}} \epsilon]$ є [ढ]MNT $\Phi$ А $\geq[$ [H NHOOY]

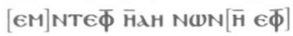
[T]NTWN $€ \Pi \bar{C} H[P € M]$ [MN]OYTe $\epsilon \bar{\phi} \overline{C O O T[} \mathbf{N}$ ] [о]үннв С̈двох jest [bez-ojca]

[i bez-]matki, [że nie

[wspomina się] jego zro[dzenia ( $\gamma \varepsilon v \varepsilon \alpha ́)]$

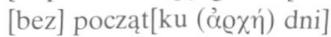

[bez] końca ży[cia, będąc]

[po]dobny do sy[na]

[Bożego], będ[ąc]

[ka]płanem na wieki

Jeśli rekonstrukcja tekstu została przeprowadzona poprawnie nie ulega wątpliwości, że jest to niemal dosłowny cytat z Hbr 7, $3^{45}$. Zdaniem B.A. Pearsona, właśnie Hbr 7, 3 należy uważać za klucz do interpetacji całego P.Bal $52^{46}$. Rekonstrukcja wykazuje jednak pewne gramatyczne nieregularnoś$\mathrm{ci}^{47}$. Koptyjski przekład greckiego tekstu $\mathrm{Hbr}$ 7, $3 \mathrm{w}$ dialekcie bohairskim zakłada orzeczenie éotiv i jest tłumaczone jako zdanie nominalne: „bez ojca, bez matki" (оүдтішт оүдтмаү пє) ${ }^{48}$. Tymczasem wersja saidzka (wg edycji Thomsona) zdaje się zakładać zdanie względne: єүגтєıшт пє єүхтмגаү пє

${ }^{43}$ Można jednak zaryzykować stwierdzenie, iż w wersecie 75 litery [...]థ̄̄[...] należały do wyrażenia аф ф̆ooc Nגi (,,powiedział mi”), które mogło stanowić podsumowanie odpowiedzi udzielonej przez pośrednika objawienia, lub $\mathbf{\alpha} \overline{\mathbf{q}} \mathbf{0 O c} \mathrm{N \lambda} \Phi$ (,powiedział jemu”), co z kolei byłoby fragmentem dialogu pomiędzy Kainem a Bogiem; por. Kahle, Bala'izah, t. 1, s. 473.

${ }^{44}$ Tak m.in. Kahle, Bala'izah, t. 1, s. 476-477; Crum, Coptic Anecdota, s. 178; Gianotto, Melchisedek e la sua tipologia, s. 192.

45 Por. Crum, Coptic Anecdota, s. 178, przyp. 12; Kahle, Bala'izah, t. 1, s. 476-477. Horton fragment ten określa (The Melchizedek Tradition, s. 135) mianem ,,a direct paraphrase”; zob. także Gianotto, Melchisedek e la sua tipologia, s. 192.

46 Por. Pearson, The Figure of Melchizedek in Gnostic Literature, s. 110.

47 Por. Till , Zu den koptischen Texten aus Bala'izah, s. 394-395.

48 G.W. Horner, The Coptic Version of the New Testament in the Northern Dialect Otherwise Called Memphitic and Bohairic, with Introduction, Critical Apparatus, and Literal English Translation, vol. 3, Osnabrück 1969, 498. 
(,który jest bez-ojca, który jest bez-matki”) ${ }^{49}$. Kahle w swej edycji uzupełnia pierwszy zwrot jak w prostym zdaniu nominalnym, drugi jednak łączy z zachowanym prefiksem $\mathbf{\epsilon}-$, opuszczając zarazem zaimek пє, na który w rękopisie nie ma miejsca. Według Tilla rekonstrukcja taka jest niepoprawna i tekst ten powinien raczej brzmieć podobnie, jak w edycji Thompsona, a więc єүатєıшт пє lub оүатєıшт єүатмдаү пє, gdyż zdanie rozpoczynające się od partykuły względnej $€$ - musi tworzyć pełne wyrażenie, a nie występować jako pojedyncze substantivum. Stąd też Till kwestionuje poprawność uzupełnienia єүaтmady w wersecie 83 bez następującej po nim partykuły zdania nominalnego $\pi \epsilon^{50}$ ?

Należy sądzić, że w dalszej części mogła pojawić się gnostycka interpretacja cytowanego tekstu, podejmująca kwestie znaczenia imienia Melchizedeka, jego pochodzenia i typologii chrystostologicznej. Niestety, rękopis urywa się w tym miejscu, a ostatnie zachowane zdanie można zrekonstruować jako formułę wprowadzającą cytat: „powiedziano o nim (że)”, tym razem już bez partykuły

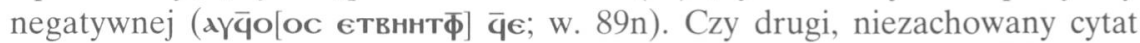
pochodził z Księgi Rodzaju lub z Ps 109, 4 LXX? Należałoby tego oczekiwać, jeśli istotnie było zamiarem autora tekstu przekazanie wyjaśnienia trudności egzegetycznych, związanych z postacią Melchizedeka. Być może jednak w dalszym ciągu po prostu cytowany był tekst $\mathrm{z} \mathrm{Hbr}^{51}$.

Czy na tej podstawie można już wskazać na motywy wspólne dla tekstu z Bala'izah i Hbr? O tym, że oba teksty mogła cechować podobna teologia wskazuje fakt odwoływania się do typologii tych samych figur biblijnych, mianowicie Kaina i Abla (Hbr 11, 2), Noego i arki (Hbr 11, 7) oraz oczywiście Melchizedeka (cytat Hbr 7, 3). Nie wydaje się, aby zestawienie takie było dziełem przypadku. Oto raz jeszcze wykaz niewątpliwych paralelizmów:

${ }^{49}$ H. Thompson, The Coptic Version of the Acts of the Apostles and Pauline Epistles in the Sahidic Dialect, Cambridge 1932, 174.

${ }^{50}$ Por. Till , Zu den koptischen Texten aus Bala'izah, s. 395.

51 Por. Pearson, The Figure of Melchizedek in Gnostic Literature, s. 110. Postać Melchizedeka w Liście do Hebrajczyków pojawia się przede wszystkim w rozdz. 7, w kontekście objaśnienia arcykapłańskiej posługi Chrystusa. Autor Hbr dokonuje reinterpretacji tekstów Rdz 14, 18-20 w świetle Ps 110, 4 w kontekście powszechnego i nieprzemijającego kapłaństwa Zbawiciela, dla którego Melchizedek jest szczególną figurą. Jego imię tłumaczy się jako „król pokoju” i „król sprawiedliwości”, a brak zapisanej genealogii wyjaśnia jako zapowiedź odwieczności Syna Bożego i nieprzemijającą trwałość Jego kapłaństwa. Także uroczysta przysięga z Ps 110, 4 jest dowodem wyższości kapłaństwa Chrystusa nad posługą lewitów, sprawowaną na podstawie Prawa Mojżeszowego. Interpretacja ta miała zasadniczy wpływ na literaturę chrześcijańską, której przedstawiciele odwoływali się do postaci Melchizedeka w różnych kontekstach. Na temat egzegezy Hbr i zawartej w niej interpretacji postaci Melchizedeka zob. szerzej w: M.C. Parsons, Son and High Priest. A Study in the Christology of Hebrew, EQ 60 (1988) 195-216; A. Vanhoye, Prêtres anciens, Prêtre nouveau selon le Nouveau Testament, Paris 1980; tenże, La lettre aux Hébreux. Jésus-Christ médiateur d'une alliance nouvelle, Paris 2002. Obszernie na temat patrystycznej egzegezy postaci Melchizedeka w różnych tradycjach zob. R. Zarzeczny, Melchizedek w literaturze wczesnochrześcijańskiej i gnostyckiej, Katowice (w przygotowaniu). 
P.Bal 52 w. $47-56=\operatorname{Hbr} 11,2$; w. 71-72= Hbr 11, 7; w. 82-89= Hbr 7, 3. W tym kontekście należałoby zastanowić się nad związkiem tradycji reprezentowanych w P.Bal z objawieniami, jakie spotykamy w pismach judeochrześcijańskich $^{52}$. W kontekście gnostyckim, gdzie idea sekretu odgrywa ogromną rolę, tajemnicze wyrażenie „bez ojca [i] bez matki” (Hbr 7, 3) mogłoby również stanowić element tradycji sekretnej ${ }^{53}$. Prawdopodobnie wymagałoby to przyjęcia, że istotnie tekst wprowadzał dyskusję chrystologiczną, w której Melchizedek pełnił rolę figury ( $\tau u ́ \pi o \varsigma)$ Zbawiciela, jaką wyznacza mu List do Hebrajczyków i czego ważny ślad możemy zaobserwować w traktacie z NHC IX.1. Niestety, obecny stan zachowania fragmentu P.Bal 52 nie pozwala na dalej idące wnioski.

4. Identyfikacja Melchizedeka z Semem? Kwestia Melchizedeka pojawia się bezpośrednio po wyjaśnieniu dziejów Noego, lub nawet - jak to już zaznaczaliśmy - stanowi część tego wyjaśnienia. Jeśli zawiesić sugestię całkowitej zależności tej części P.Bal 52 od schematu zapisanego w Hbr, raz jeszcze można postawić pytanie o klucz doboru figur i ich wzajemny związek: czy taka sekwencja jest tylko dziełem przypadku? W narracji biblijnej epizod z Melchizedekiem spotykamy dopiero w Rdz 14, 18-20 w ramach opowieści o wojennej

52 Przykładem teologii zbudowanej w oparciu o sekret mesjański może być Wniebowstapienie Izajasza, które opisuje proces zstępowania Chrystusa z siódmego nieba przez wszystkie sfery kosmosu przybierając postać ich mieszkańców, aby nie być rozpoznanym (WnbIz 10, 8-31), a rodząc się w ludzkiej postaci zachowuje wszelkie pozory człowieczeństwa $(11,17)$; chociaż Jego narodzeniu towarzyszy seria cudownych wydarzeń (por. 11, 2-16), to jednak ,pozostało ukryte przed wszystkimi niebiosami i wszystkimi książętami i przed wszystkimi bogami tego świata" (11, 16). Na temat schematu chrystologicznego w tym szczególnym piśmie zob. U. Bianchi, L'Ascensione d'Isaia. Tematiche soteriologiche di descensus-ascensus, w: M. Pesce (wyd.), Isaia, il Diletto e la Chiesa, Brescia 1983, 155-178; elementy gnostyckie przeanalizował A.K. Helmbold, Gnostic Elements in the 'Ascension of Isaiah', NTS 18 (1972) 222-226.

${ }^{53} \mathrm{Na}$ tle braku genealogii Melchizedeka rodziły się liczne spekulacje, prowadzone zwłaszcza we wspólnotach heterodoksyjnych, pozostających na marginesie Wielkiego Kościoła. Według autorów starożytnych pism erezjologicznych miało to dowodzić jego niebiańskiego pochodzenia.

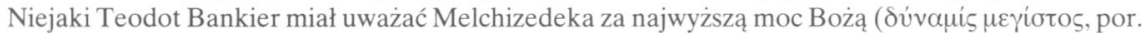
Ps.-Hippolytus, Refutatio VII 35-36, PG 16, 3342), przyznając mu anielską naturę (Ps.-Tertullianus, Adversus omnes haereses VIII 3, PSP 29, 219-220) i uważając za większego od Chrystusa (Epiphanius, Panarion 54, 1, GCS 31, 317). Z kolei Hierakas z Egiptu miał go identyfikować z Duchem Świętym (Epiphanius, Panarion 55, 5, GCS 31, 330-331); por. R. Zarzeczny, Pneumatologia Hierakasa $z$ Egiptu na tle apokryficznego Wniebowstąpienia Izajasza $i$ starożytnych tradycji melchizedekiańskich, VoxP 26 (2006), t. 49, 735-748. Ojcowie Kościoła zwracają uwagę, że słowa Hbr 7, 3 „,bez ojca, bez matki, bez rodowodu” odnoszą się do Chrystusa „który jako człowiek narodził się bez ojca, a jako Bóg bez matki, i który nie ma rodowodu, gdyż napisane jest: «rodzaj jego kto wypowie»?" (Ambrosius, De fide 3, 89, CSEL 78, 140, tłum. I. Bogaszewicz: Św. Ambroży, O wierze, Warszawa 1970, 104; por. Marcus Eremita, De Melchisedech 4, 8-10, SCh 455, 188; Cyrillus Alexandrinus, Homilia II de Melchisedech (aethiop.) 5, w: B.M. Weischer (ed.), Qērellos, t. IV/3, Wiesbaden 1980, 110. 
wyprawie Abrahama; jednak do tej historii fragment z Bala’izah nie odwołuje się wcale. Pewną pomocą w wyjaśnieniu roli Melchizedeka w tej części dokumentu może być znana w literaturze żydowskiej i chrześcijańskiej tradycja identyfikacji tajemniczego króla - kapłana z biblijnym synem Noego, mianowicie Semem. Identyfikację taką odnajdujemy już w pismach żydowskich, począwszy od targumów do Księgi Rodzaju ${ }^{54}$. Motyw powraca w późniejszych tekstach rabinicznych w kontekście polemiki z chrześcijańską interpretacją kapłaństwa Melchizedeka i jego wyższości nad kapłaństwem Lewitów ${ }^{55}$. Z kolei w literaturze chrześcijańskiej łączenie Melchizedeka z Semem było szczególnie rozpowszechnione w środowiskach orientalnych, czego świadectwem jest syryjski tekst Jaskini Skarbów (IV w.), ale motyw ten spotykamy także w innych pismach ${ }^{56}$. Jaskinia Skarbów opowiada bibljną historię świata jako kronikę dziejów zbawienia, od stworzenia aż do Chrystusa ${ }^{57}$. Praojciec Adam pozostawia w testamencie przekazanym na łożu śmierci nakaz zatroszczenia się o jego doczesne szczątki, tak aby po potopie mogły być pochowane w miejscu wskazanym przez Boga, którym później okazuje się być Golgota. Dlatego także Noe na łożu śmierci wzywa potajemnie swojego syna Sema i nakazuje mu przenieść szczątki Adama do groty znajdującej się w centrum świata, wraz z darami złota, kadzidła i mirry, które prarodzice zabrali opuszczając ogród Eden. W wyprawie tej towarzyszyć mu będzie jego prawnuk Melchizedek; w jednej z wersji Jaskini Skarbów Melchizedek jest tożsamy z Semem, tak jak w pismach żydowskich. Na miejscu, w którym zostaną pochowane szczątki

54 Por. M. McNamara, Melchisedek: Gen 14, 17-20 in the Targums, in Rabbinic and Early Christian Literature, „Biblica” 72 (2000) 1-31. Teksty Targumu Neofiti i tzw. Targumu Fragmentarycznego wyjaśniają, że Melchizedek to ,wielki Sem”, natomiast Targum Pseudo-Jonatana mówi wprost, że owym sprawiedliwym królem z Rdz 14, 18 jest „Sem syn Noego”.

${ }_{55}$ Por. zwłaszcza M. Simon, Melchisédech dans la polémique entre juifs et chrétiens et dans la légende, w: Recherches d'histoire judéo-chrétienne, Paris 1962, 104. Starożytność takiej idei w obrębie judaizmu potwierdza fragment z traktatu Nedarim w Talmudzie babilońskim (b.Ned 32b). Tekst ten zdaje się przekazywać bardzo starą tradycję, gdyż za pośrednictwem rabbi Zachariasza (IV wiek) powołuje się na opinię rabbi Ismaela, należącego do drugiej generacji tanaitów, współczesnego sławnemu rabbi Akibie (ok. 50-135 n.e.). Ta sama tradycja powraca w żydowskich midraszach (np. GenR 20, 6; 26, 3; NmR 4, 8; LvR 20, 1; 25, 6) dla wykazania, że w istocie kapłaństwo Melchizedeka przeszło na Abrahama. Według Zachariasza Retora (Historia ecclesiastica, CSCO 83 / syr. 38, 13, tłum. łac. CSCO 87 / syr. 4, 8) tradycja łączenia obu postaci wśród Żydów była powszechna.

56 Są to przeważnie pisma związane z tzw. cyklem Adama, mianowicie etiopska Walka Adama i Ewy, również etiopski Qalementos oraz syryjski Testament Adama. Ponadto wśród pisarzy chrześcijańskich identyfikację potwierdzają także św. Efrem (Commentarius in Genesin 11, 2, CSCO 152 / syr. 71, 68-69, tłum. łac. CSCO 153 / syr. 72, 55-56), Hieronim (Epsitula 73, 5 i Lib. quaest. hebr. in Gen. 14, 18, PL 23, 961) oraz Epifaniusz z Salaminy (Panarion 55, 6, 1). Z poglądem takim w środowisku syryjskim dyskutował też Iszodad z Merw (IX wiek), nestoriański biskup Hadatty (por. Commentarius in Genesin 14, 18, CSCO 126/syr. 67, 147).

57 Por. wydanie A. Su-Min Ri, CSCO 486/syr. 207, Louvain 1987, thum. franc. CSCO 487/syr. 208, Louvain 1987. 
Adama, Melchizedek pozostaje na zawsze, by pełnić tam funkcję kustosza relikwi, kapłana Boga Najwyższego oraz króla miasta, które później otrzyma nazwę Salem. W tym samym miejscu Abraham składać będzie ofiarę z Izaaka, a Chrystus umrze na krzyżu, przynosząc odkupienie wszystkim pokoleniom ${ }^{58}$. Pismo to łączy różne motywy żydowskie, chrześcijańskie i gnostyckie ${ }^{59}$. Być może tradycja wiążąca Melchizedeka z osobą Sema i wywodząca go z rodu Noego znana była również autorowi fragmentarycznego traktatu z Deir elBala'izah $^{60}$. Zapytanie Jana mogło zatem dotyczyć roli, jaką według tej tradycji Melchizedek odegrał w pochowaniu relikwii praojca Adama po potopie ${ }^{61}$.

Inna analogia pomiędzy P.Bal 52 a tekstami związanymi z postacią Melchizedeka, w tym także z tekstem Jaskini Skarbów, dotyczy motywu pięciu drzew rajskich. Pisma związane z cyklem Adama szczegółowo opisują stworzenie Adama z czterech elementów i umieszczenie Prarodziców w raju w sposób wyraźnie inspirowany przez tardycje gnostyckie ${ }^{62}$. Podobnie w apokryficznej Księdze Henocha słowiańskiej anioł zabiera Melchizedeka, który rodzi się już w sposób cudowny jako kapłan, i umieszcza go w Raju ${ }^{63}$. W tym samym kontekście warto zwrócić uwagę na obecność idei niebiańskiego kapłaństwa Melchizedeka w jednym z pism qumrańskich, mianowicie Pieśni ofiary szabatowej $(4 \mathrm{Q} 401)^{64}$. Wydaje się, że wszystkie te teksty wiąże jakaś wspólna tradycja, której jednak w pełni nie potrafimy odtworzyć. W świetle powyższych

58 Por. obszerny komentarz do tekstu Jaskini Skarbów, również autorstwa A. Su-Min Ri, Commentaire de la Caverne des trésors. Étude sur l'histoire du texte et de ses sources, CSCO 581/ subs. 103, Louvain 2000.

${ }^{59}$ Por. Su-Min Ri, Commentaire, s. 277n; A. Böhlig, Der Judenchristliche Hintergrund in gnostischen Schriften von Nag Hammadi, w: Mysterion und Wahrheit, Leiden 1968, 102-111; G. Widengren, Synkretismus in der syrischen Christenheit, w: A. Dietrich (ed.), Synkretismus im syrisch-persischen Kulturgebiet, Göttingen 1975, 38-64.

${ }^{60}$ Tak sądzi np. B.A. Pearson (The Figure of Melchizedek in Gnostic Literature, s. 110).

61 Por. Horton, The Melchizedek Tradition, s. 134.

${ }^{62}$ Wskazuje się na szczególne podobieństwo z ApokrJ (NHC II.1 14, 13-34) i Pismem bez tytułu o początku świata (NHC II.5 107-108); por. Su-Min Ri, Commentaire, s. 134-137.

${ }^{63}$ Por. 2 Hen 71, 6-8, tłum. R. Rubinkiewicz, Apokryfy Starego Testamentu, Warszawa 1999, 214. W Henochu stowiańskim raj znajduje się w trzecim niebie, w połowie drogi do podnóża tronu Pańskiego (2Hen 8-9). Miejsce to zostało przygotowane na schronienie dla ludzi sprawiedliwych jako ich wieczne dziedzictwo $(2$ Hen 9,1$)$. Koncepcja ta przypomina strukturę kosmosu według walentyniańskich gnostyków, por. Jonas, Religia gnozy, s. 59. Podobne ujęcie znajdujemy jednak także w literaturze judaistycznej, gdzie raj stanowi jeden z elementów całej struktury mistycznej, opisywanej pojęciami zaczerpniętymi z apokaliptyki żydowskiej. W talmudycznym traktacie $\mathrm{Ha}$ giga, gdzie obserwujemy podział górnych rejonów świata na siedem niebios, w połowie kosmicznej „drabiny” znajduje się idealna świątynia wraz z ołtarzem (por. b.Hag 12b); podobna sytuacja występuje w Midraszu do Dziesięciu Przykazań, przy czym mowa jest tu o archaniele Michale, który składa ofiary jako arcykapłan.

${ }^{64}$ Chodzi zwłaszcza o fragment nr 11; por. C.A. Newsom, Songs of Sabbath Sacrifice. A Critical Edition, Atlanta 1985, 131. Obszerniej na ten temat zob. F. Manzi, Melchisedech e l'angelologia nell'Epistola agli Ebrei e a Qumran (AnBibl 136), Roma 1997, 40-41. 
paraleli tekst z Bala'izah zdaje się być gnostyckim opracowaniem chrześcijańskich tradycji przyjmującym formę egzegetycznego midraszu, sporządzonym prawdopodobnie na użytek adeptów jakiejś gnostyckiej wspólnoty, wywodzących się z Wielkiego Kościoła, a przynajmniej zaznajomionych z doktryną chrześcijańską. Jak wskazano powyżej nie można też wykluczyć bezpośrednich związków z jakąś starożytną tradycją żydowską.

APOCRYPHAL DIALOGUS IOHANNIS CUM IESU (CAPNT 27) AS A GNOSTIC REINTERPRETATION OF PATRIARCHAL STORY AND A COMMENTARY TO HEBR. 7:3

(Summary)

This article contains Polish translation and commentary to an apocryphal Gnostic text known as Dialogus Johannis cum Iesu (CApNT 27). The fragmental Coptic manuscript from the Deir el-Bala'izah collection (IV/V century A.D.) is the unique known testimony of this document. The text has a form of dialog between John the Apostle and the Risen Christ or some celestial messenger on creation and story of antediluvian patriarchs. Document reveals a particular similitude with other Gnostic texts, especially the Apocryphon of John from the Nag Hammadi library. It conserves the fragment of Hebr. 7:3, which probably received a large explanation in original document. The speculation on biblical personages, especially on Melchisedek, appears to be an important element in this text. The placement of Melchisedek's name immediately after the name of Noah may suggests the identification of Melchisedek with Shem, the Noah's son. Similar motif is known to us from the Jewish and ancient Christian literature, for instance the targumic elaborations of Genesis and the Syriac apocryphal text called Cave of Treasures (Spelunca thesaurorum). 